\title{
Paleoceanography
}

\section{RESEARCH ARTICLE \\ 10.1002/2014PA002632 \\ Late Holocene sea level variability and Atlantic Meridional Overturning Circulation}

Key Points:

- Sea level oscillations are a persistent feature of late Holocene climate

- Sea level variations reflect Atlantic Meridional Overturning Circulation

- Distinguishing causes of sea level patterns should consider ocean processes

Supporting Information:

- Readme

- Text S1

Correspondence to:

T. M. Cronin,

tcronin@usgs.gov

\section{Citation:}

Cronin, T. M., J. Farmer, R. E. Marzen, E. Thomas, and J. C. Varekamp (2014), Late Holocene sea level variability and Atlantic Meridional Overturning Circulation, Paleoceanography, 29, doi:10.1002/2014PA002632.

Received 20 FEB 2014 Accepted 26 MAY 2014 Accepted article online 2 JUN 2014 use tide gauges and tidal marsh sediments to understand global sea level rise.

\author{
T. M. Cronin ${ }^{1}$, J. Farmer ${ }^{2}$, R. E. Marzen ${ }^{1}$, E. Thomas ${ }^{3,4}$, and J. C. Varekamp ${ }^{4}$ \\ ${ }^{1}$ U.S. Geological Survey, Reston, Virginia, USA, ${ }^{2}$ Now at Lamont-Doherty Earth Observatory, Columbia University, Palisades, \\ New York, USA, ${ }^{3}$ Geology and Geophysics, Yale University, New Haven, Connecticut, USA, ${ }^{4}$ Earth and Environmental \\ Sciences, Wesleyan University, Middletown, Connecticut, USA
}

Abstract Pre-twentieth century sea level (SL) variability remains poorly understood due to limits of tide gauge records, low temporal resolution of tidal marsh records, and regional anomalies caused by dynamic ocean processes, notably multidecadal changes in Atlantic Meridional Overturning Circulation (AMOC). We examined SL and AMOC variability along the eastern United States over the last 2000 years, using a SL curve constructed from proxy sea surface temperature (SST) records from Chesapeake Bay, and twentieth century SL-sea surface temperature (SST) relations derived from tide gauges and instrumental SST. The SL curve shows multidecadal-scale variability (20-30 years) during the Medieval Climate Anomaly (MCA) and Little Ice Age (LIA), as well as the twentieth century. During these SL oscillations, short-term rates ranged from 2 to $4 \mathrm{~mm} \mathrm{yr}^{-1}$, roughly similar to those of the last few decades. These oscillations likely represent internal modes of climate variability related to AMOC variability and originating at high latitudes, although the exact mechanisms remain unclear. Results imply that dynamic ocean changes, in addition to thermosteric, glacio-eustatic, or glacio-isostatic processes are an inherent part of SL variability in coastal regions, even during millennial-scale climate oscillations such as the MCA and LIA and should be factored into efforts that

\section{Introduction}

Sea level rise (SLR) ranks high on the list of climate change issues due to its threats to coastal regions. Instrumental (tide gauge and satellite) records show that mean global SLR rates were $0.6 \mathrm{~mm} \mathrm{yr}^{-1}$ and $1.9 \mathrm{~mm} \mathrm{yr}^{-1}$ during the nineteenth and twentieth centuries, respectively, $1.7 \pm 0.3 \mathrm{~mm} \mathrm{yr}^{-1}$ since 1950 Common Era (C.E., total $\sim 10 \mathrm{~cm}$ ), and $3.3 \pm 0.4 \mathrm{~mm} \mathrm{yr}^{-1}$ from 1993 to 2009 C.E. (total $\sim 5.2 \mathrm{~cm}$ ) [Douglas et al., 2001; Jevrejeva et al., 2008; Nicholls and Cazenave, 2010]. Based on tide gauges, tidal marsh records, and glacio-isostatic adjustment (GIA) modeling, it has been argued that sea level (SL) was stable during the past few millennia, and then sea level rise accelerated $~ 1850-1900$ C.E. [e.g., Kemp et al., 2011; Church and White, 2011]. Our poor understanding of multidecadal SL variability, however, implies that it is questionable whether we can confidently identify a twentieth century acceleration of sea level rise based on tide gauge records of limited length [Sallenger et al., 2012; Ezer and Corlett, 2012; Gehrels and Woodworth, 2013]. In addition, regional SL is impacted by multiple factors that must be taken into account (Figure 1), in contrast to global sea level studies, which focus on thermosteric changes (ocean thermal expansion) in ocean volume and eustatic changes (ice melt and freshwater storage) in ocean mass.

Marsh and coastal sediments along eastern North America have provided classic sea level reconstructions for the Holocene [Bloom and Stuiver, 1963; Scholl et al., 1969] and the last few millennia [Thomas and Varekamp, 1991; Varekamp et al., 1992; Nydick et al., 1995; Varekamp and Thomas, 1998; Kearney and Stephenson, 1991]. Despite many additional marsh sea level reconstructions [Engelhart et al., 2009; Kemp et al., 2011] (reviewed in Gehrels [2010]), sea level variability in the last 2000 years remains poorly understood, in part because marsh accretion is better suited for documenting sea level rise than sea level fall [Varekamp et al., 1992; Kemp et al., 2011]. In addition, ocean dynamical processes associated with Atlantic Meridional Overturning Circulation (AMOC) can overwhelm thermosteric and eustatic effects along some coastlines. Climate modeling and instrumental records show a dynamical relationship between sea surface temperature (SST) and SL in the North Atlantic, related to AMOC variability over various timescales [Frankcombe and Dijkstra, 2009]. Moreover, AMOC-forced SL anomalies are amplified along the eastern United States so that tide gauges in this region serve as an indirect proxy for changes in the strength of AMOC [Bingham and Hughes, 2009; Ezer and Corlett, 


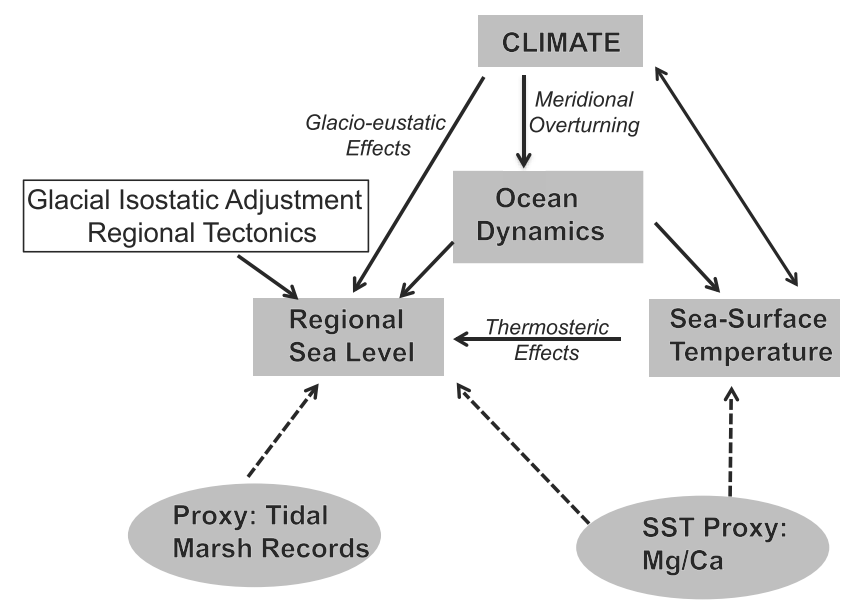

Figure 1. Processes influencing regional sea level variability along coastlines.
2012; Ezer, 2013; Kopp, 2013]

(see section 2). However, instrumental records of AMOC only go back to the 1950s [Bryden et al., 2005], and records of the Gulf Stream to the 1930s [Rossby et al., 2010]. There are no high-resolution proxy records of either Holocene sea level or AMOC; thus, it remains difficult to assess whether AMOC persistently influences sea level variability.

In this study, we use a sea surface temperature (SST) reconstruction based on magnesium-calcium $(\mathrm{Mg} / \mathrm{Ca})$ data from Chesapeake Bay (CB) sediment cores [Cronin et al., 2010] (Figure S1 in the supporting information) to reconstruct regional SL patterns off the eastern U.S.

over the last 2000 years, to estimate past variability in SL and, by inference, AMOC. In addition to the relation between AMOC and sea level discussed below, our approach is based on several factors. First, the high Holocene sedimentation rate (on average decadal resolution or better) makes this record superior to those from tidal marshes and other marine sediment records [Heslop and Paul, 2011, but see Boessenkool et al., 2007]. Second, sea level change reconstructed from SST proxies is free from the complicating effects of vertical land motions caused by tectonic, GIA, and other processes. Finally, an empirical approach to SL reconstruction has been used successfully to assess global sea level based on the observed relations between global sea level and near-surface temperature [Rahmstorf, 2007; Vermeer and Rahmstorf, 2009; Grinsted et al., 2009; Schaeffer et al., 2012].

We first discuss the connection between sea level and AMOC based on modeling studies, paleoceanographic records, and instrumental records. We then quantify the relationship between SL and SST along the eastern United States for the last century-which we call "SL sensitivity"—using instrumental SST and tide gauge records. Sensitivity estimates are then used to construct late Holocene SL anomaly curves from the $\mathrm{Mg} / \mathrm{Ca}$-based proxy SST reconstruction from Chesapeake Bay, which are compared to late Holocene SL curves constructed from eastern U.S. tidal marsh records.

\section{AMOC, SST, and Sea Level in the North Atlantic}

\subsection{Atlantic Meridional Overturning Circulation}

Atlantic Meridional Overturning Circulation is driven by vertical mixing in the ocean's interior and windinduced Ekman upwelling in the Southern Ocean, with volume transport and circulation influenced by heat and freshwater fluxes at the ocean surface [Kuhlbrodt et al., 2007; Srokosz et al., 2012]. Model simulations of the last millennium forced by volcanism, solar variability, and greenhouse gases [Hofer et al., 2011] and model simulations of the last 4000 years with atmosphere, ocean, land, and sea ice components of unforced climate variability [Delworth and Zeng, 2012] show transient reductions in AMOC. Records from the Dry Tortugas/ Great Bahama Banks region suggest up to a $10 \%$ weakening of AMOC flow through the Florida Strait during the Little Ice Age (LIA) 1400-1800 C.E., with a minimum near 1800 C.E. [Lund and Curry, 2006; Lund et al., 2006], but the temporal resolution is too low to assess short-term variability. Trouet et al. [2009] used tree ring records from Morocco and speleothems from Scotland to infer that a 1000 year North Atlantic record of the North Atlantic Oscillation may be linked to changes in AMOC, but terrestrial records are only indirectly related to ocean dynamic changes.

Climate variability in the North Atlantic Ocean during the twentieth century involved large SST and SL anomalies [Bingham and Hughes, 2009; Deser et al., 2010; Lozier et al., 2010], reflecting changes in the strength of AMOC [Levermann et al., 2005; Yin et al., 2009; Hofer et al., 2011; Liu, 2012]. This AMOC variability led to regional SL anomalies of $\pm 4 \mathrm{~mm} \mathrm{yr}^{-1}$ in the subpolar and subtropical North Atlantic between 1950-1970 and 1980-2000, which predate and postdate the large 1970s shift in the North Atlantic Oscillation (NAO) [Lozier 
(a) Dynamic SL- Observations (1992-2002, m)

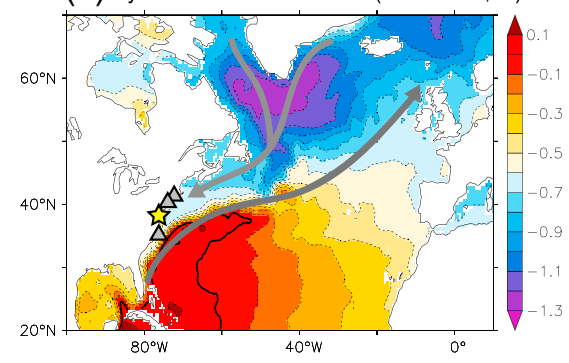

(b) Dynamic SL- Simulation (1992-2002, m)

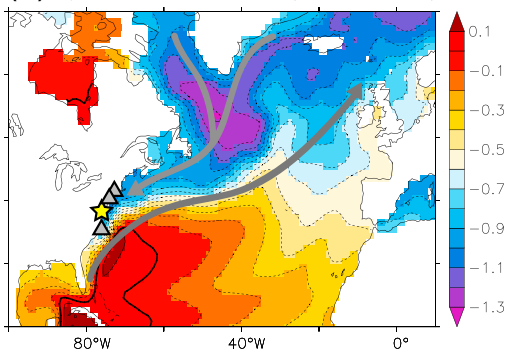

Figure 2. Dynamic sea levels (in meters) from observations and from the Geophysical Fluid Dynamic Laboratory Climate Model (CM2.1) simulations. (a) Observations (1992-2002) [Maximenko and Niiler, 2005]. (b) Simulation (1992-2002) [Yin et al., 2009]. Location of Chesapeake Bay (star); Connecticut, New Jersey, and North Carolina marshes (triangles). Grey arrows show northeast flowing Gulf Stream-North Atlantic Drift and southwest flowing east Greenland/Labrador Currents. Modified from Yin et al. [2009] with permission from Macmillan.

et al., 2010]. These anomalies are far larger than the basin-averaged rate (non-glacio-eustatic) of $\sim 0.25 \mathrm{~mm} \mathrm{yr}^{-1}$ between 1950 and 2000 .

Off the eastern U.S., sea level anomalies in instrumental and historical records are particularly high. For example, Bingham and Hughes [2009] suggested that a $2 \mathrm{~cm}$ fall in regional SL corresponds to a 1 sverdrup (Sv) increase in AMOC. The Geophysical Fluid Dynamics Laboratory Climate Model (CM2.1) also shows large regional sea level anomalies along the eastern U.S. A sharp gradient in dynamic sea level across the Gulf Stream-North Atlantic Drift system was observed between 1992 and 2002, associated with the position of the subpolar gyre, in observations (Figure 2a) and model simulations (Figure 2b) (adopted from Yin et al. [2009]). Negative SL anomalies along the northeast U.S. coast reach -0.5 to $-1.0 \mathrm{~m}$ during this period. In contrast, Yin et al.'s [2009] simulations of "freshwater hosing" (i.e., simulation of fresh water influx) into the North Atlantic for the next century show AMOC weakening, resulting in positive SL anomalies off northeastern North America. Such regional rates of SL variation due to AMOC weakening can reach $20-25 \mathrm{~mm} \mathrm{yr}^{-1}$ and up to 4-5 cm/Sv under extreme freshwater forcing [Levermann et al., 2005]. The modeled ocean response to future Greenland ice mass loss shows a decrease in the strength of AMOC and relative SL rise along eastern North America (15,54, and $165 \mathrm{~cm}$ of SL rise by 2100 depending on the model simulation) [Hu et al., 2009]. The total increase in regional sea level is $10-30 \mathrm{~cm}$ in the subpolar North Atlantic, contrasting with a decrease of $10-20 \mathrm{~cm}$ in the midlatitude North Atlantic.

\subsection{AMOC and the Atlantic Multidecadal Oscillation}

We hypothesize that increases (decreases) in the strength of AMOC reflecting internal climate variability are linked to negative (positive) regional sea level anomalies along the eastern U.S., following Bingham and Hughes [2009], Ezer [2013], and Yin et al. [2009] (Figure 2). One dominant mode of variability illustrating the relation between SL and North Atlantic Ocean processes is the Atlantic Multidecadal Oscillation (AMO) [Enfield et al., 2001; te Raa and Dijkstra, 2002; Dijkstra et al., 2006; Frankcombe and Dijkstra, 2009]. AMO variability along the U.S. East Coast during the early to middle twentieth century is illustrated through comparison of instrumental and proxy records (Figure 3). These records include a composite SL anomaly record from nine tide gauges (TG) along the northeast coast of North America [Bingham and Hughes, 2009] (Figure 3a), detrended TG records from Baltimore and New York (Figure 3b) [see Boon, 2012], mean annual Hadley Centre Sea Ice and Sea Surface Temperature (HadISST) records in the Atlantic Ocean adjacent to Chesapeake Bay $\left(37.5^{\circ} \mathrm{N}, 75.5^{\circ} \mathrm{W}\right.$ ) (Figure 3c) [Rayner et al., 2003], the proxy SST paleoreconstruction from CB cores (Figure 3d) [Cronin et al., 2010], and the AMO SST index for the North Atlantic (http://www.esrl.noaa. gov/psd/data/correlation/amon.us.long.data) (Figure 3e). All exhibit the well-known pattern of rising temperature and sea level beginning about 1920 (low AMO), peaking in the 1950s (high AMO), then falling in the 1960s and 1970s. Collectively, these records show that SST and SL in Chesapeake Bay, and the northwestern North Atlantic Ocean, exhibit similar trends on 20-30 year timescales, with positive sea level and SST anomalies corresponding to a positive AMO index. These patterns are consistent with empirical and modeling evidence suggesting that changes in AMOC might be a forcing mechanism for AMO variability [Delworth and Zhang, 2007; Frankcombe and Dijkstra, 2009]. 


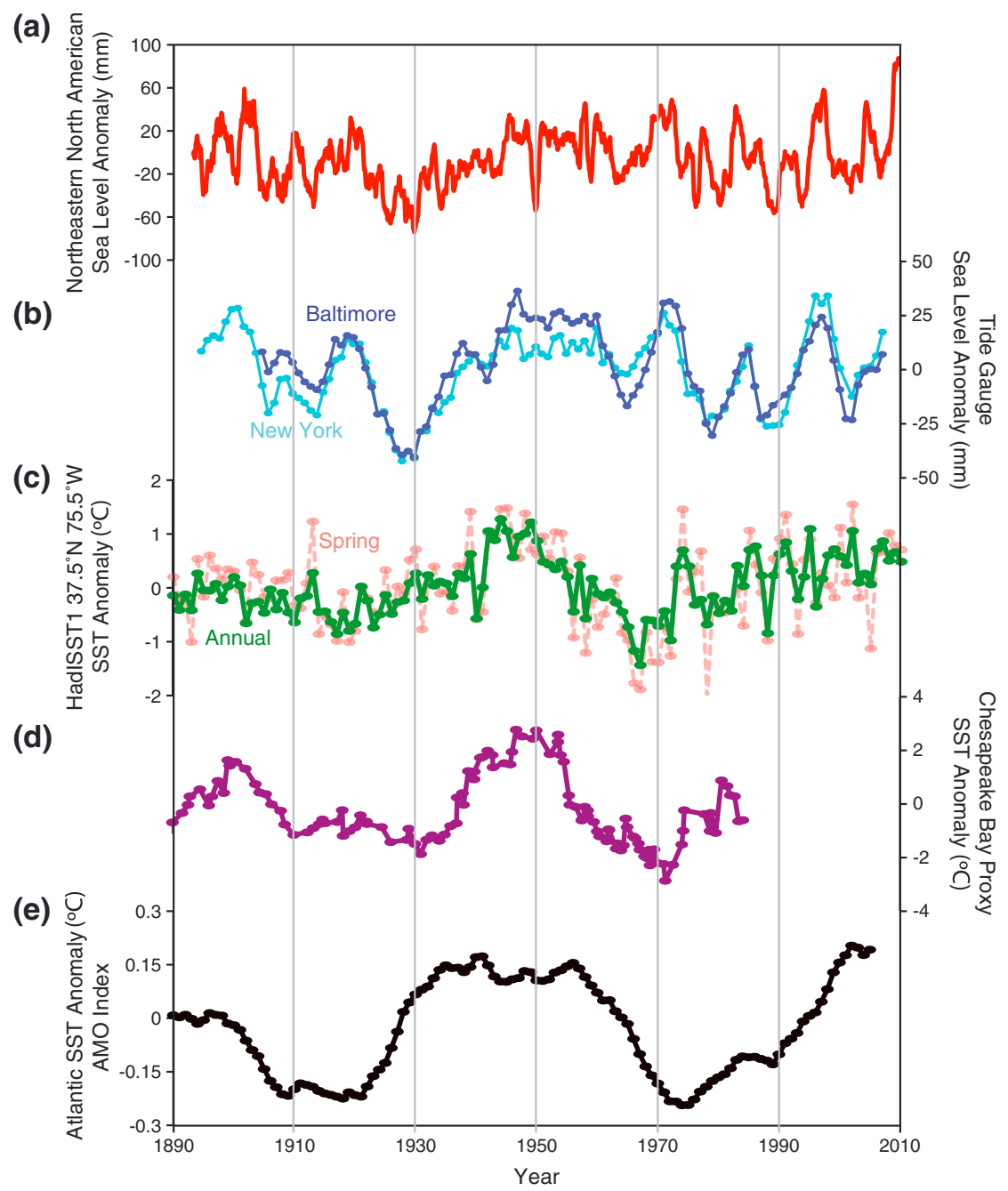

Figure 3. (a) Northeastern North American detrended sea level anomaly based on 10 tide gauges from New York to Yarmouth, Nova Scotia [Bingham and Hughes, 2009], (b) Baltimore and New York detrended tide gauge records (5 point running mean) (http://www.psmsl.org/data/obtaining), (c) Mean Annual and Spring (average March to May) SST anomaly from HadISST1 (37.5 $\mathrm{N}, 75.5^{\circ} \mathrm{W}$ ) (http://www.metoffice.gov.uk/hadobs/hadisst/data/download.html), (d) Mg/Ca-derived proxy SST anomaly record for Chesapeake Bay (9 point running mean), and (e) Atlantic Multidecadal Oscillation North Atlantic SST index, Kaplan version 2, (http://www.esrl.noaa.gov/psd/data/correlation/amon.us.long.data).

In addition to 20-30 year oscillations, Schlesinger and Ramankutty [1994] and Delworth and Mann [2000] document 50-70 year quasi-cyclic climate oscillations on a North Atlantic basin scale. A 60 year oscillation in global mean sea level is also evident in tide gauge records from most ocean basins, except the North Pacific [Chambers et al., 2012]. The relations between 20-30 year and 50-70 year patterns are not clear (see section 5), but both patterns may be related to meridional overturning, atmospheric NAO-like variability, and AtlanticArctic Ocean water exchange [see Frankcombe et al., 2010].

\section{Methods}

We first evaluated the relations between Chesapeake Bay water temperatures and Atlantic Ocean SST data because of the short length of instrumental SST records. We then estimated the "sensitivity" of SL to SST by quantifying the relation between Atlantic Ocean SST data and sea level elevation anomalies in detrended CB tide gauge records. Finally, the SL-SST sensitivity for CB SST was obtained using the relation between calculated Atlantic Ocean SST and CB SST. 


\subsection{Chesapeake Bay and Western North Atlantic SST}

The relationship between Chesapeake Bay and Atlantic Ocean source water temperatures is evaluated using instrumental records. The data for Chesapeake Bay SST are monthly averages (1949 to 2011 when available) from shallow water $(<8 \mathrm{~m}$ ) at monitoring segments CB4MH and CB5MH (Figure S1; http://www.

chesapeakebay.net/data/). Water temperatures are highly correlated between the two monitoring segments $\left(r^{2}=0.99\right.$, Figure S2), suggesting that shallow water temperatures are similar throughout the main stem of the bay, where the sediment Mg/Ca-derived proxy SST records were obtained.

Atlantic Ocean SST data were taken from the monthly HadISST1 data set [Rayner et al., 2003] at the $37.5^{\circ} \mathrm{N}$, $75.5^{\circ} \mathrm{W}$ grid point outside the mouth of $\mathrm{CB}$. The linear least squares regression between monthly Atlantic Ocean and Chesapeake Bay SST data since 1949 suggest that CB SST and adjacent Atlantic Ocean SST are linearly correlated $\left(r^{2}=0.96\right)$ and that a $\sim 0.86^{\circ} \mathrm{C}$ Atlantic Ocean SST increase corresponded to a $1^{\circ} \mathrm{C}$ increase in CB SST over the period 1949-2011 (Figure S2). These results are consistent with studies showing the influence of ocean source water from the mid-Atlantic continental shelf on CB temperatures [Cronin et al., 2010].

\subsection{Sensitivity of Sea Level to Changes in SST}

To obtain the sensitivity of regional sea level to changes in SST, we compared the oceanic SST record from the HadISST1 data set at $37.5^{\circ} \mathrm{N}, 75.5^{\circ} \mathrm{W}$ to a composite CB SL curve based on six tide gauge records, each with at least 45 years of data (minimum 45 years, maximum 108 years), from 1929 to 2010 (Baltimore, Annapolis, Solomons Island, Kiptopeke, Gloucester Point, and Sewells Point-Hampton Roads; http://psmsl.org/data/ obtaining; Figures S1 and S3). The composite tide gauge record was detrended to compare processes influenced by regional dynamics rather than steric, eustatic, or glacio-isostatic effects, and an 11 year moving average was applied to both the HadISST1 and the composite CB TG record to filter subdecadal variation (supporting information). CB SL and Atlantic Ocean SST records exhibit similar multidecadal trends (Figure 4a), roughly in phase during the 1935-1950 AMO oscillation (Figure 3). We obtain a SL-SST sensitivity from tide gauges and SST data for the period 1935 to 1950 of $2.25 \mathrm{~cm}$ of SL change per ${ }^{\circ} \mathrm{C}$ in ocean SST $\left(r^{2}=0.84, \sigma=0.27 \mathrm{~cm}^{\circ} \mathrm{C}^{-1}\right.$; Figure $4 \mathrm{c}$ ), which, multiplied by the conversion factor 0.86 (section 3.1), yields a sensitivity value for Chesapeake Bay of $1.94 \mathrm{~cm}$ SL change per ${ }^{\circ} \mathrm{C}$ change in CB.

Between 1950 and 2006, SL appears to lag SST (Figure 4a), a pattern consistent with studies of the relationship between SST and SL variation with respect to the changing strength of the AMOC [Wyatt et al., 2011]. For this period, the linear least squares regression between Atlantic Ocean SST and the detrended Chesapeake Bay SL anomalies with a lag time of 18 years maximizes the linear correlation (Figure $4 b$ ). This suggests that a $1^{\circ} \mathrm{C}$ increase in Atlantic Ocean SST corresponded to $1.71 \mathrm{~cm}$ increase in CB SL $\left(r^{2}=0.56\right.$, $\sigma=0.25 \mathrm{~cm}^{\circ} \mathrm{C}^{-1}$; Figure $4 \mathrm{~d}$ ) over this time period. Thus, a $1.48 \mathrm{~cm}$ increase in CB SL corresponded to $1^{\circ} \mathrm{C}$ increase in CB SST when adjusted by the CB SST-Atlantic Ocean SST relation described above.

\section{3. $\mathrm{Mg} / \mathrm{Ca}$ SST Paleothermometry}

To reconstruct the CB SL variability over the past 2000 years, we applied the 1.94 and $1.48 \mathrm{~cm}$ sensitivity values to paleo-SST records generated from magnesium/calcium $(\mathrm{Mg} / \mathrm{Ca}$ ) paleothermometry [Cronin et al., 2003, 2010; Vann et al., 2004]. $\mathrm{Mg} / \mathrm{Ca}$ in calcite $\left(\mathrm{CaCO}_{3}\right)$ shells of the ostracode Loxoconcha (crustacea) is controlled by the water temperature at which the adult animal grows its shell during molting. We slightly modified the original empirical $\mathrm{Mg} / \mathrm{Ca}$ temperature calibration $\left(T=0.644 \times \mathrm{Mg} / \mathrm{Ca}-2.428 ; r^{2}=0.81\right)$ from Cronin et al. [2003], based on 156 living and core top Loxoconcha from CB, Bogue Sound North Carolina, and the Atlantic continental shelf off eastern North America, by including additional material from Dameron Marsh and the York River in Chesapeake Bay [Vann et al., 2004; Cronin et al., 2005]. The full calibration data set includes samples representing seasonal and latitudinal variability in water temperature covering a range of 7 to $30^{\circ} \mathrm{C}$. The revised calibration (equation (1)) is based on 265 individual analyses of adults from 56 samples, including samples yielding two or more $\mathrm{Mg} / \mathrm{Ca}$ analyses:

$$
\begin{aligned}
& T=0.61 \times \mathrm{Mg} / \mathrm{Ca}-0.415 \\
& \left(r^{2}=0.77, \sigma=2.9\right)
\end{aligned}
$$

where $T$ is the $\mathrm{CB}$ surface water temperature in ${ }^{\circ} \mathrm{C}$ and $\mathrm{Mg} / \mathrm{Ca}$ is the value of magnesium to calcium in mmol/ mol. This equation was used to compute paleo-SSTs from Loxoconcha from sediment cores from the main channel of CB. The age model used by Cronin et al. [2010] was revised slightly by recalibrating radiocarbon 


\section{a. Multidecadal trends in SL anomalies and SST}
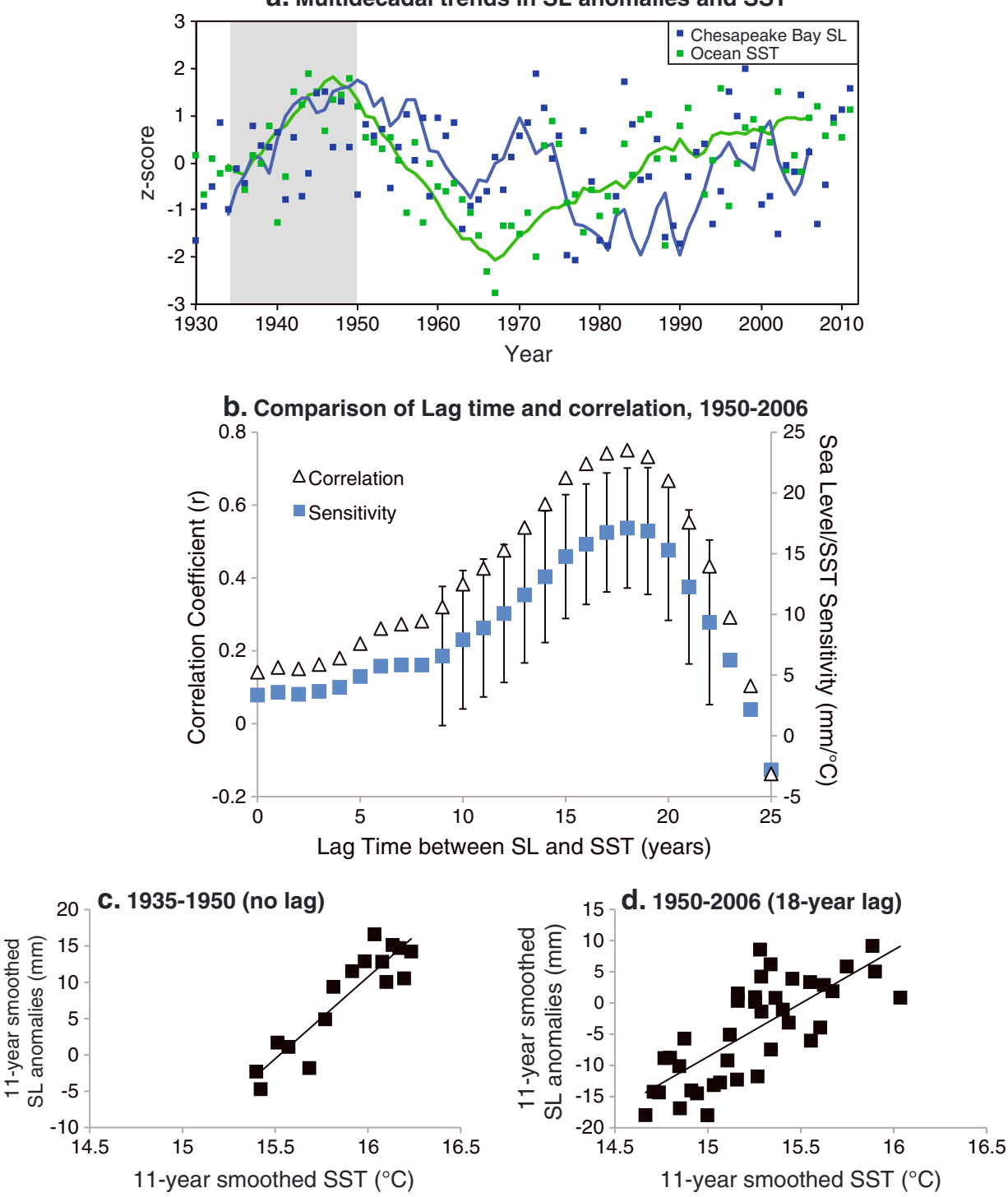

Figure 4. (a) Instrumental records of yearly (squares) and 11 year smoothed (lines) Chesapeake Bay sea level anomalies (blue) and HadISST oceanic SST (green) [Rayner et al., 2003]. Both data sets are plotted as $z$ score, with the units corresponding to number of standard deviations from the data set mean. (b) Comparison of correlation between SST and SL (triangles), and sensitivity of SL to SST (expressed as the slope of the linear best fit line, blue boxes), as a function of lag time between SL and SST in years. Error bars on sensitivity indicate the \pm 2 standard error range on the slope of the best fit line between SL and SST and are only shown for lag times that produce a correlation coefficient ( $r$ ) greater than 0.3. (c and d) Scatterplots of SL anomaly versus SST for the 1935-1950 and 1950-2006, 18 year lagged periods.

dates using the CALIB 6.0 program [Reimer et al., 2004; Stuiver et al., 2012; http://calib.qub.ac.uk/calib/]. This revision changed the numerical ages minimally from -200 before the Common Era (B.C.E.) to 900 C.E. and after 1600 C.E., and by a few decades between 900 and 1600 C.E. The largest change was the twelfth century negative temperature excursion, which is 40 years younger in the new age model (Figure 5).

\subsection{Uncertainty of SST-Based SL Estimates}

The cumulative uncertainty on sea level estimates based on the Chesapeake Bay paleotemperature record is estimated from the following sources of error: (1) Stacking of Chesapeake Bay detrended tide gauge records (Stack); (2) Calibration of Mg/Ca to CB SST (Mg); (3) Cross calibration of SST records from the two Chesapeake Bay monitoring areas $\left(\mathrm{CB}_{\text {sst }}\right) ;(4)$ Cross calibration of SST records from Chesapeake Bay and the HadISST data 


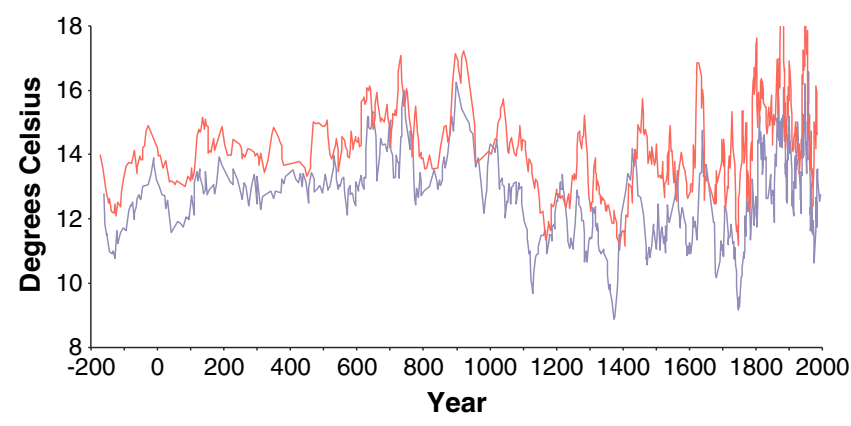

Figure 5. Composite $\mathrm{Mg} / \mathrm{Ca}$-derived Chesapeake water temperatures in ${ }^{\circ} \mathrm{C}$ using old age model [Cronin et al., 2010] and age model derived in the current study, using CALIB 6.0 marine reservoir-corrected ages [Reimer et al., 2004; Stuiver et al., 2012] (http://calib.qub.ac.uk/calib/). set (SST oce); $_{\text {; }}$ Cross calibration of the HadISST data set and the stacked, detrended $C B$ tide gauge records ( $\left.\mathrm{SL}_{\mathrm{sst}}\right)$.

The uncertainty in Stack is evaluated as the average of the yearly stacking standard error:

$$
\mathrm{SE}_{\text {Stack }}=\frac{1}{(2012-1928)} \sum_{i=1928}^{2012} \frac{\sigma_{i}}{\sqrt{n_{i}}}
$$

where $\sigma_{i}$ is the standard deviation of the stack in the $i$ th year and $n_{i}$ is the number of tide gauge records averaged in the ith year. Uncertainty in the detrending regressions for each tide gauge was not propagated to the stack uncertainty, as the regressions are meant to center the tide gauge records and remove long-term trend in the mean.

For $\mathrm{Mg}, \mathrm{CB}_{\text {sst }}, \mathrm{SST}_{\text {oce, }}$ and $\mathrm{SL}_{\text {sst }}$, uncertainty is expressed as 1 standard error of the least squares estimate for the slope of the regression line between both data sets $\left(\mathrm{SE}_{m}\right.$, Table S1). Vertical uncertainty on the sea level estimate was calculated as the quadrature sum of the fractional uncertainties for each term above:

$$
\frac{\delta \mathrm{SL}}{|\mathrm{SL}|}=\sqrt{\left(\frac{\mathrm{SE} \mathrm{E}_{\text {stack }}}{|\mathrm{Stack}|}\right)^{2}+\left(\frac{\mathrm{SE}_{m_{\mathrm{Mg}}}}{\left|m_{\mathrm{Mg}}\right|}\right)^{2}+\left(\frac{\mathrm{SE}_{m_{\text {CBsst }}}}{\left|m_{\mathrm{CBss}}\right|}\right)^{2}+\left(\frac{S E_{m_{\text {SSToce }}}}{\left|m_{\text {SSToce }}\right|}\right)^{2}+\left(\frac{\mathrm{SE}_{m_{\text {SLsst }}}}{\left|m_{\text {SLsst }}\right|}\right)^{2}}
$$

where $\mid$ Stack $\mid$ is the range of the detrended stack and $m$ is the slope of the respective regression lines. The resulting vertical uncertainty $(\delta \mathrm{SL})$ is expressed as a percentage of the range of reconstructed $\mathrm{SL}(|\mathrm{SL}|)$. Propagation of error by summation in quadrature assumes that the errors of the individual components in equation (3) are independent and random. In practice this independence is difficult to discern, but there is no a priori reason to expect the terms in equation (3) to exhibit dependency outside the considered relations.

Using the regression parameters in Table S1 results in a $1 \sigma$ vertical uncertainty of $15.4 \%$ using the 1935-1950 SST to SL calibration, and 17.5\% using the 1950-2006 18 year lagged SST to SL calibration. Accounting for the ranges of reconstructed SL from both SST to SL calibrations, this corresponds to a $1 \sigma$ uncertainty of $\pm 6.6 \mathrm{~cm}$ using the 1935-1950 SST to SL calibration, and $\pm 5.8 \mathrm{~cm}$ using the 1950-2006 18 year lagged SST to SL calibration. These estimates compare favorably with expressed vertical uncertainties in tidal marsh sea level records from the east coast of North America (Table 1).

\section{Results}

\subsection{Construction of a 2000 Year Regional Sea Level Anomaly Curve}

The maximum and minimum SL-SST sensitivities $\left(1.94 \mathrm{~cm}\right.$ and $1.48 \mathrm{~cm}$ per $\left.{ }^{\circ} \mathrm{C}\right)$ applied to the SST anomalies from the $\mathrm{Mg} / \mathrm{Ca}$ curve yield the sea level anomaly curves shown in Figure 6 . These curves reflect departures from mean regional sea level averaged over the last 2000 years. Multidecadal sea level oscillations characterize the entire record from 200 B.C.E. to 2000 C.E., with multiple brief ( 20 years), large $(14$ to $20 \mathrm{~cm})$

Table 1. Vertical Uncertainties From Common Era Sea level Reconstructions, East Coast USA

\begin{tabular}{lccc} 
Approach & Location & 1 Sigma Vertical Uncertainty $(\mathrm{cm})$ & References \\
\hline Tidal marsh & Connecticut, USA & $3.9-5.2$ & Donnelly et al. [2004] \\
Tidal marsh & North Carolina, USA & 5 & Kemp et al. [2011] \\
Empirical SL-SST & Chesapeake Bay, USA & $5.8-6.6$ & this study \\
Tidal marsh & Connecticut, USA & $5-20$ & van de Plassche et al. [1998] \\
Tidal marsh & New Jersey, USA & 12 & Kemp et al. [2013] \\
Tidal marsh & Connecticut, USA & 15 & Thompson et al. [2000] \\
Tidal marsh & Maine, USA & 25 & Gehrels [2000] \\
\hline
\end{tabular}




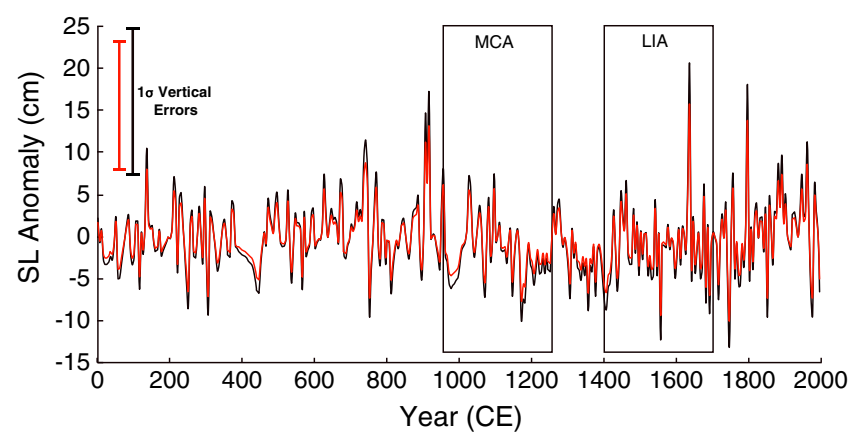

Figure 6. Ten year interpolated paleo-sea level anomaly curves using 1.94 (black) and $1.48 \mathrm{~cm} /{ }^{\circ} \mathrm{C}$ (red) sensitivities described in text, age model modified from Cronin et al. [2010] (Figure 5). MCA and LIA are Medieval Climate Anomaly and Little Ice Age. excursions. Estimated rates of regional SL rise and fall during these $\sim 20$ year periods are $\sim 2$ to $4 \mathrm{~mm} \mathrm{yr}^{-1}$, roughly equivalent to the average modern Chesapeake Bay SL rise rate of $\sim 3.5 \mathrm{~mm} \mathrm{yr}^{-1}$ uncorrected for GIA-related subsidence. CB rates over periods as far back as 1903 range from 3.1 to $5.0 \mathrm{~mm} \mathrm{yr}^{-1}$, depending on the tide gauge [Boon, 2012]. Our ability to reconstruct processes influencing $S L$ on longer timescales (e.g., centennial or greater) is constrained by the use of detrended tide gauge records in the SST to SL calibration. Hence, multicentennial

SL events are not observed in the CB record, even though persistent features in eastern U.S. tidal marsh records [Thompson et al., 2000; Kemp et al., 2011, 2013] (see below and Figure 8).

\subsection{Quasi-Cyclic SL Variability Over Multidecadal Timescales}

To analyze the periodicity of SL variability, we calculated the frequency domain of the CB sea level reconstruction for the last 2000 years, at an average temporal resolution of 3.0 years. Data were regularly resampled at 5 year intervals to remove subdecadal frequencies of variation (Figure 7). Significant multidecadal variation (at 80\% confidence) appears at periods centered on 21 and 31 years, with significant power on multicentennial timescales ( 185 years). Additional spectral analyses (not shown) of the SL record using different sampling and smoothing strategies and covering both the last 1000 years and the period 1713-1990 C.E. suggested the presence of similar periods of multidecadal variability.

\subsection{Tidal Marsh Records of Sea Level}

We aimed to examine whether multidecadal-scale regional SL variations are a persistent feature of the NE USA region during past climate changes; thus, we plotted the curve (Figure 6) against low-frequency SL variability records over the Medieval Climate Anomaly (MCA) and LIA based on tidal salt marsh sediments. Marsh SL records for the MCA-LIA have negligible tectonic influence and well-constrained long-term GIA

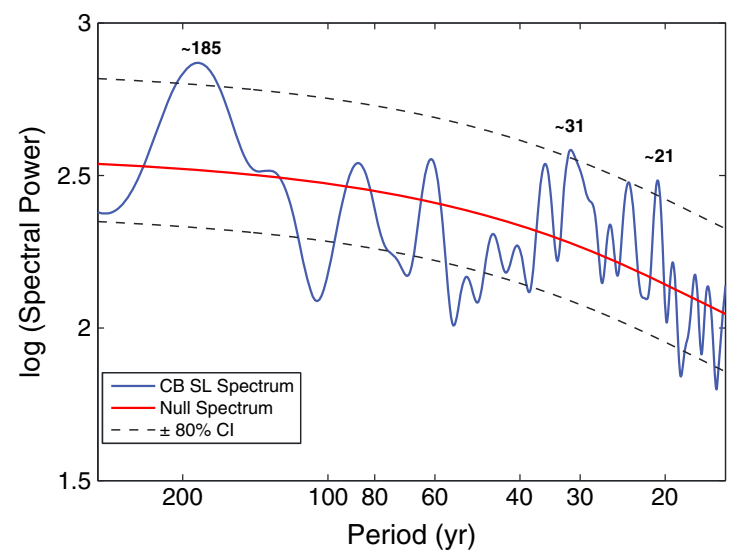

Figure 7. Blackman-Tukey fast Fourier transform of the paleoSL curve interpolated at 5 year intervals, with Bartlett windowing at $30 \%$ of the series length. The bandwidth is $0.003 \mathrm{y}^{-1}$. The null spectrum is estimated as a third-order polynomial fit to the logarithm of the power spectrum. Significant power at the $80 \%$ confidence level is observed relative to the null spectrum at periods of $\sim 21$ (20.1 to 21.4) years, 31 (29.9 to 32.9 ) years, and 185 (144 to 256 ) years, with bandwidth intervals given in parentheses.
[Engelhart et al., 2009; Varekamp et al., 1992; Kemp et al., 2011, 2013] and exhibit variability associated with the large-scale late Holocene millennial-scale climate oscillations.

Figure 8 shows late Holocene sea level anomaly curves for Connecticut (Figure $8 \mathrm{a}, \sim 41.5^{\circ} \mathrm{N}$ latitude, (T) [Thomas and Varekamp, 1991; Varekamp et al., 1992; Varekamp and Thomas, 1998; Thompson et al., 2000], New Jersey (Figure $8 b, \sim 39-39.5^{\circ} \mathrm{N}$ latitude, NJ) [Kemp et al., 2013], and Pamlico-Albemarle Sound, eastern North Carolina (Figure $8 \mathrm{~d}, \sim 35-36^{\circ} \mathrm{N}$ latitude, NC) [Kemp et al., 2011]. The CT record is a composite based on three marshes (Branford, Guilford, and Clinton) located within a $25 \mathrm{~km}$ area. The curves were constructed using long-term average rates of sea level rise calculated from the slope of the linear least squares fit between sediment age and relative sea level position derived using agglutinated benthic foraminiferal records. Longterm average rates are $2.1 \mathrm{~mm} \mathrm{yr}^{-1}$ for $\mathrm{CT}$, $1.55 \mathrm{~mm} \mathrm{yr}^{-1}$ for NJ and $1.18 \mathrm{~mm} \mathrm{yr}^{-1}$ for Sand 

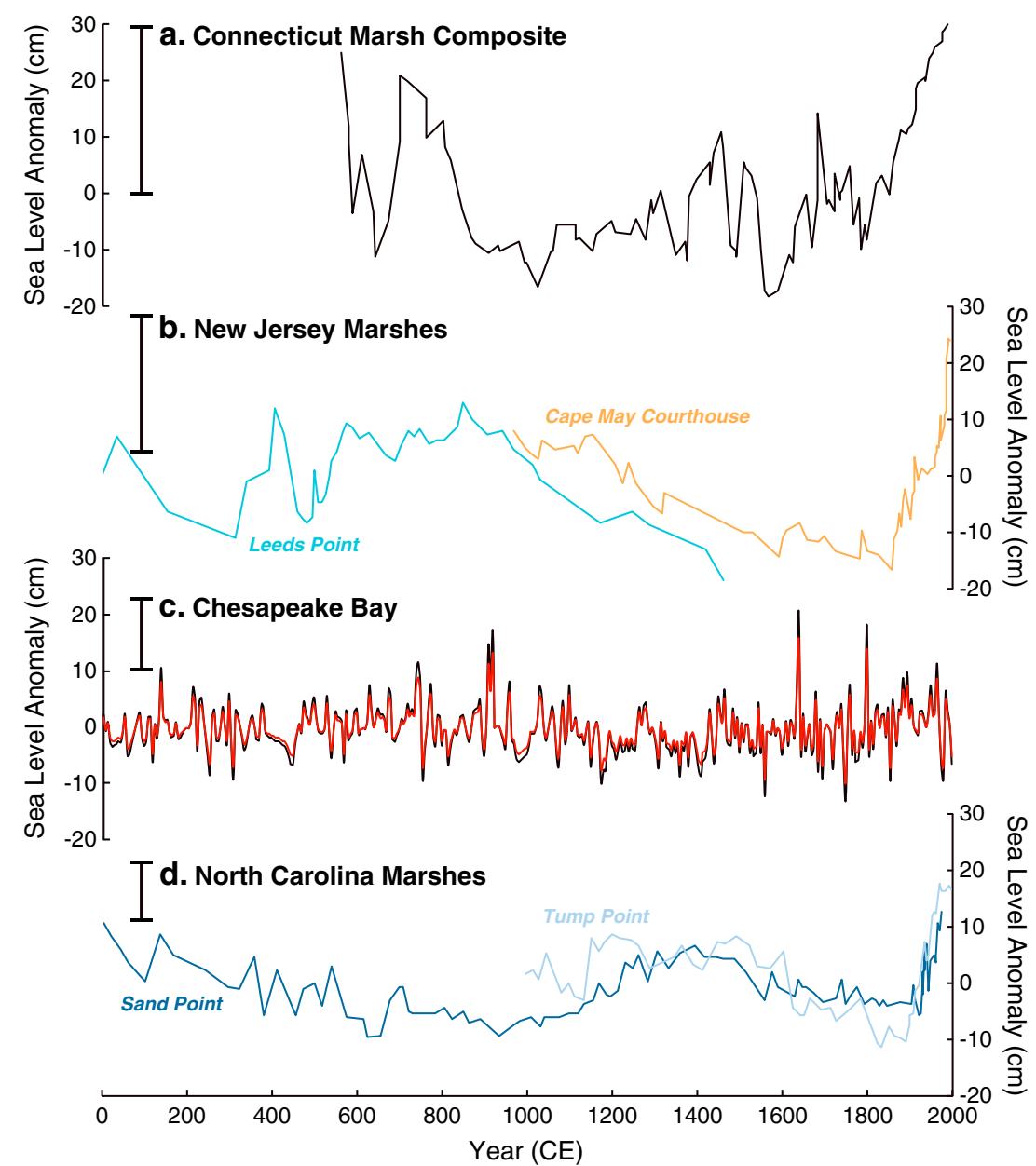

Figure 8. Detrended sea level anomalies for tidal marsh sea level records calculated as departure from long-term SL rise rates for (a) Connecticut marshes (Branford, Guilford, and Clinton) [Thompson et al., 2000], (b) New Jersey marshes (Leeds Point and Cape May Courthouse) [Kemp et al., 2013], and (d) North Carolina marshes (Sand Point and Tump Point) [Kemp et al., 2013]. Chesapeake Bay multidecadal SL anomalies from Figure 6 are shown in Figure 8c. Uncertainty interval based on foraminiferal assemblages varies among saltmarsh and by location within a saltmarsh, with lowest values $(\sim 10 \mathrm{~cm})$ in the upper marsh and larger values $(\sim 25-30 \mathrm{~cm})$ in the middle marsh.

Point, NC (higher rates of $2.3 \mathrm{~mm} \mathrm{yr}^{-1}$ were obtained for Dennis Creek, NJ, by Varekamp and Thomas [1998]). Estimates of SL rise rates vary depending on estimates of GIA subsidence and period considered, but the slightly different rates do not appreciably alter the pattern of centennial-scale sea level variability (supporting information).

The CT and NJ curves from Kemp et al. [2013] have positive SL anomalies during the MCA ( 700-900 C.E. in CT, 600-1200 C.E. in NJ; Figure 8). The fall in SL during the MCA-LIA transition occurred after 1000 C.E. and more gradually in NJ [Kemp et al., 2013]. In contrast, there was relatively high SL in NC prior to 600 C.E. and from 1200 to 1500 C.E. [Kemp et al., 2011]. Two other differences between the curves are the amplitude of SL variability across the MCA-LIA transition. This amplitude decreases from north to south ( 30 to $40 \mathrm{~cm}$ in CT, 20 to $30 \mathrm{~cm}$ in NJ, and 10 to $20 \mathrm{~cm}$ in NC). Marsh records from the Gulf of Mexico, for comparison, show a MCA-LIA SL anomaly conservatively estimated at $0-55 \mathrm{~cm}$, with a likely anomaly in the range of tens of centimeters [González and Törnqvist, 2009]. Modeled global SL anomalies during the MCA-LIA based on landbased temperature reconstructions are $\sim 31-47 \mathrm{~cm}$ [Grinsted et al., 2009] and $25 \mathrm{~cm}$ [Crowley et al., 2003].

The multidecadal SL variations of 10 to $20 \mathrm{~cm}$ estimated from the paleo-SST record (Figure 8c) occur throughout the last 2000 years, including the MCA-LIA intervals, when the tidal marsh records document higher-amplitude $(20-30 \mathrm{~cm})$ centennial-scale SL changes and inflection points representing periods of rising 
or falling SL [Kemp et al., 2013]. These results suggest a persistent pattern of regional multidecadal SL variability during both warmer (MCA) and cooler (LIA) late Holocene periods.

\section{Discussion}

\subsection{Sources of Uncertainty}

To our knowledge, we are the first to estimate past regional sea level anomalies using an SST-based proxy method and to examine the SL-AMOC relation over multidecadal timescales. We consider these results preliminary and subject to several sources of uncertainty. As with all sedimentary records, the knowledge about the exact timing of reconstructed events hinges on the quality of the age models. Chesapeake sediment chronology has been the subject of numerous studies using several chronological methods $\left({ }^{210} \mathrm{~Pb},{ }^{137} \mathrm{Cs},{ }^{14} \mathrm{C}\right.$, historical pollen-colonial land use change), has been replicated in multiple sediment cores, and is considered accurate to within several decades [Colman et al., 2002; Willard et al., 2005; Cronin et al., 2010]. In tidal marshes, age error bars may be several decades to a century, depending on the particular marsh, method used, and time period [Thomas and Varekamp, 1991; Varekamp et al., 1992; Gehrels, 2010; Kemp et al., 2013].

There is also an error associated with the Mg/Ca proxy method and the SL-SST sensitivity equations used to convert SST to SL anomalies, only in part due to the possible lag between regional SL, SST, and AMOC strength ( $1 \sigma$ vertical error \pm 5.8 to $6.6 \mathrm{~cm}$ SL equivalent, Table 1). The range of reconstructed SL anomalies ( $\sim 20 \mathrm{~cm}$, Figure 6 ) exceeds the range of SL anomalies used for calibration ( $2.5 \mathrm{~cm}$, Figure $4 \mathrm{~b})$, so there likely is additional uncertainty from the extrapolation of our SL-SST sensitivity calibration. In addition, AMOC variability occurs over seasonal to interannual timescales, beyond the temporal resolution of proxy-based SL records [Rayner et al., 2011; McCarthy et al., 2012]. We therefore emphasize that inferences about past AMOC variability using paleo-SST and SL reconstructions represent simplified, semiquantitative views of a complex system.

\subsection{High-Frequency $A M O C$ and Sea Level Oscillations}

Even with these uncertainties, the SL anomaly curves in Figure 6 reveal patterns that may be explained by dynamical ocean changes related to AMOC variability, similar to those observed in many studies of east coast tide gauges [Bingham and Hughes, 2009; Sallenger et al., 2012; Ezer and Corlett, 2012; Ezer, 2013], as well as model simulations [Hu et al., 2009; Yin et al., 2009]. Exact triggering mechanisms are difficult to assess, but changes in the mass balance of the Greenland Ice Sheet could have periodically altered the strength of AMOC through the effects of freshwater flux on surface ocean density. Supporting this idea, a strong southeast geographic information system melting event during the 1930s [Bjørk et al., 2012] coincided with the rise in sea level during the twentieth century AMO oscillation (Figure 3). In addition, this hypothesis is consistent with 8000 year long ice core, lake, and marine sediment proxy records around the North Atlantic Ocean, showing quasi-cyclic AMO atmospheric variability [Knudsen et al., 2011].

Tidal marsh records from Connecticut, New Jersey, and North Carolina all exhibit evidence of SL variability on multidecadal timescales (Figure 8), although in many instances it is within vertical and horizontal uncertainties [e.g., Kemp et al., 2011, 2013]. The magnitude of multidecadal variability appears to decrease from north $(\sim 10-20 \mathrm{~cm}, \mathrm{CT})$ to south $(\sim 5 \mathrm{~cm}, \mathrm{NC})$, consistent with the expected spatial pattern of SL changes forced by AMOC variability [Yin et al., 2009]. Short-term variability in SL rise rates in some CT marshes (specifically in eastern CT, i.e., relatively close to the open ocean) has been attributed to hurricane overwash and infilling of eroded marsh sediments [e.g., van de Plassche et al., 2006], but these phenomena have not been observed in the marsh records shown here (Figure 8). The ability of tidal marsh SL records to capture multidecadal variability is hampered by the relatively low accumulation rates of tidal marsh sediments, such that they may give an aliased view as compared to the higher-resolution CB record.

\subsection{Possible Periodicity of SL Oscillations}

The significant periodicity in SL variability near 20 and 30 years (Figure 7), as previously observed in records from Chesapeake Bay [Cronin et al., 2005] agrees with the hypothesis that a 20-30 year sea level oscillation is inherent to the North Atlantic system and reflects an internal ocean mode mechanism [Frankcombe and Dijkstra, 2009; te Raa and Dijkstra, 2002], possibly related to changes in AMOC [Frankcombe et al., 2010]. Quasicycles in SST patterns at frequencies of 60-80 years are seen in general circulation models [Jungclaus et al., 
2005; Vellinga and Wu, 2004] and may reflect ocean exchange processes between the Atlantic and Arctic Oceans [Frankcombe et al., 2010]. The hypothesis that high-latitude processes trigger AMOC and sea level oscillations requires further testing using high-latitude, decadal-scale proxy reconstructions.

\subsection{Periods of Rapid Sea Level Rise}

The multidecadal regional SL anomaly curve provides a unique long-term context for understanding the controversial acceleration in the rate of sea level rise during the past few decades [Sallenger et al., 2012; Kopp, 2013; Ezer, 2013]. Rates of 2-4 $\mathrm{mm} \mathrm{yr}^{-1}$ punctuate the SST-derived SL curve (Figure 6); thus, the regional eastern U.S. rates observed during the last few decades are not necessarily unusual or representative of a long-time average. Regional rapid SLR rates of several $\mathrm{cm} \mathrm{yr}^{-1}$ can occur over several decades, as expected from ocean dynamical and modeling studies.

The hypothesis that late Holocene global SL has been stable [e.g., Bindoff et al. 2007] rests largely on local and regional tide gauge and tidal marsh records which have been corrected for GIA, but, importantly, not for variability related to $\mathrm{AMOC}$, or they cannot resolve such variability. This hypothesis has recently been questioned [e.g., Cronin, 2012; Kemp et al., 2013] and thus should be reevaluated using quantitative reconstructions of AMOC and records from higher latitudes [e.g., Gehrels et al., 2012].

\section{Acknowledgments}

Many thanks to T. Törnqvist, J. González, B. Horton, and R. Gehrels for input on marsh records, C. Hughes and S. Lozier for input on AMOC, J. Yin for sea level anomaly map shown in Figure 2, T. Ezer and H.P. Plag for comments on sea level, A. Bjørk for input on the Greenland Ice Sheet, H. Dowsett on spectral analyses, C. Bernhardt, C. Saenger, and L. Wingard for reviews. The inputs of several anonymous reviewers are greatly appreciated. Funded by USGS Global Change and Everglades Restoration Programs. J.C.V. and E.T. thank Connecticut SeaGrant for funding and Wesleyan students for their assistance in research. Data will be available at NOAA National Climatic Data Center.

\section{References}

Bindoff, N. L., et al. (2007), Observations: Oceanic climate change and sea level, In Climate Change 2007: The Physical Science Basis. Contribution of Working Group I to the Fourth Assessment Report of the Intergovernmental Panel on Climate Change, edited by S. Solomon et al., Cambridge Univ. Press, Cambridge, U. K. and New York.

Bingham, R. J., and C. W. Hughes (2009), Signature of the Atlantic Meridional Overturning Circulation in sea level along the east coast of North America, Geophys. Res. Lett., 36, L02603, doi:10.1029/2008GL036215.

Bjørk, A. A., K. H. Kjær, N. J. Korsgaard, S. A. Khan, K. K. Kjeldsen, C. S. Andresen, J. E. Box, N. K. Larsen, and S. Funder (2012), An aerial view of 80 years of climate-related glacier fluctuations in southeast Greenland, Nat. Geosci., 5, 427-432, doi:10.1038/ngeo1481.

Bloom, A. L., and M. Stuiver (1963), Submergence of the Connecticut coast, Science, 139, 332-334.

Boessenkool, K. P., I. R. Hall, H. Elderfield, and I. Yashayaev (2007), North Atlantic climate and deep-ocean flow speed changes during the last 230 years, Geophys. Res. Lett., 34, L13614, doi:10.1029/2007GL030285.

Boon, J. D. (2012), Evidence of Sea Level Acceleration at U.S. and Canadian Tide Stations, Atlantic Coast, North America, J. Coastal Res., 28, 1437-1445.

Bryden, H. L., H. R. Longworth, and S. A. Cunningham (2005), Slowing of the Atlantic Meridional Overturning Circulation at $25^{\circ} \mathrm{N}, \mathrm{Nature}, 438$, 655-657.

Chambers, D. P., M. A. Merrifield, and R. S. Nerem (2012), Is there a 60-year oscillation in global mean sea level?, Geophys. Res. Lett., 39, L18607, doi:10.1029/2012GL052885.

Church, J. A., and N. J. White (2011), Sea-level rise from the late 19th to the early 21st century, Surveys Geophys., 32, 585-602, doi:10.1007/ s10712-011-9119-1.

Colman, S. M., P. C. Baucom, J. F. Bratton, T. M. Cronin, J. P. McGeehin, D. Willard, A. R. Zimmerman, and P. R. Vogt (2002), Radiocarbon dating, chronologic framework, and changes in accumulation rates of Holocene estuarine sediments from Chesapeake Bay, Quat. Res., 57, 58-70, doi:10.1006/qres.2001.2285.

Cronin, T. M. (2012), Rapid sea-level rise, Quat. Sci. Rev., 56, 11-30.

Cronin, T. M., G. S. Dwyer, T. Kamiya, S. Schwede, and D. A. Willard (2003), Medieval Warm Period, Little Ice Age and 20th century temperature variability from Chesapeake Bay, Global Planet. Change, 36, 17-29.

Cronin, T. M., R. Thunell, G. S. Dwyer, C. Saenger, M. E. Mann, C. Vann, and R. R. Seal II (2005), Multiproxy evidence of Holocene climate variability from estuarine sediments, eastern North America, Paleoceanography, 20, PA4006, doi:10.1029/2005PA001145.

Cronin, T. M., K. Hayo, R. C. Thunell, G. S. Dwyer, C. Saenger, and D. A. Willard (2010), The Medieval Climate Anomaly and Little Ice Age in Chesapeake Bay and the North Atlantic Ocean, Palaeogeog., Palaeoclimatol. Palaeoecol., 297, 299-310, doi:10.1016/j.palaeo.2010.08.009.

Crowley, T. J., S. K. Baum, K.-Y. Kim, G. C. Hegerl, and W. T. Hyde (2003), Modeling ocean heat content changes during the last millennium, Geophys. Res. Lett., 30(18, 1932), doi:10.1029/2003GL017801.

Delworth, T. L., and M. E. Mann (2000), Observed and simulated multidecadal variability in the Northern Hemisphere, Clim. Dyn., 16, 661-676, doi:10.1007/s003820000075.

Delworth, T. L., and F. Zeng (2012), Multicentennial variability of the Atlantic Meridional Overturning Circulation and its climatic influence in a 4000 year simulation of the GFDL CM2.1 climate model, Geophys. Res. Lett., 39, L13702, doi:10.1029/2012GL052107.

Delworth, T. L., and R. Zhang (2007), Decadal to Centennial Variability of the Atlantic From Observations and Models, Geophys. Monogr. Ser., $173,131-148$.

Deser, C., M. A. Alexander, S.-P. Xie, and A. S. Phillips (2010), Sea surface temperature variability: Patterns and mechanisms, Annu. Rev. Mar. Sci., 2, 115-143, doi:10.1146/annurev-marine-120408-151453.

Dijkstra, H. A., L. A. te Raa, M. Schmeits, and J. Gerrits (2006), On the physics of the Atlantic Multidecadal Oscillation, Ocean Dyn., 56, 36-50, doi:10.1007/s10236-005-0043-0.

Donnelly, J. P., P. Cleary, P. Newby, and R. Ettinger (2004), Coupling instrumental and geological records of sea-level change: Evidence from southern New England of an increase in the rate of sea-level rise in the late $19^{\text {th }}$ century, Geophys. Res. Lett., 31, L05203, doi:10.1029/ 2003 GL018933.

Douglas, B. C., M. S. Kearney, and S. P. Leatherman (2001), Sea Level Rise: History and Consequences, International Geophysics Series, vol. 75, pp. 232, Academic Press, New York.

Enfield, D. B., A. M. Mestas-Nuñez, and P. J. Trimble (2001), The Atlantic multidecadal oscillation and its relation to rainfall and river flows in the continental, U.S, Geophys. Res. Lett., 28, 2077-2080, doi:10.1029/2000GL012745. 
Engelhart, S. E., B. P. Horton, B. C. Douglas, W. R. Peltier, and T. E. Törnqvist (2009), Spatial variability of late Holocene and 20th century sea-level rise along the Atlantic coast of the United States, Geology, 37, 1115-1118, doi:10.1130/G30360A.1.

Ezer, T. (2013), Sea level rise, spatially uneven and temporally unsteady: Why the U.S. East Coast, the global tide gauge record, and the global altimeter data show different trends, Geophys. Res. Lett., 40, 1-6, doi:10.1002/2013GL057952.

Ezer, T., and W. B. Corlett (2012), Is sea level rise accelerating in the Chesapeake Bay? A demonstration of a novel new approach for analyzing sea level data, Geophys. Res. Lett., 39, L19605, doi:10.1029/2012GL053435.

Frankcombe, L. M., and H. A. Dijkstra (2009), Coherent multidecadal variability in North Atlantic sea level, Geophys. Res. Lett., 36, L15604, doi:10.1029/2009GL039455.

Frankcombe, L. M., A. von de Heydt, and H. A. Dijkstra (2010), North Atlantic multidecadal climate variability: An investigation of dominant time scales and processes, J. Clim., 23, 3626-3638, doi:10.1175/2010JCLI3471.1.

Gehrels, W. R. (2000), Using foraminiferal transfer functions to produce high-resolution sea-level records from salt-marsh deposits, Maine, USA, Holocene, 10, 367-376.

Gehrels, W. R. (2010), Sea-level changes since the Last Glacial Maximum: An appraisal of the IPCC Fourth Assessment Report, J. Quat. Sci, 25(1), 26-38, doi:10.1002/jqs.1273.

Gehrels, W. R., and P. L. Woodworth (2013), When did modern rates of sea-level rise start?, Global Planet. Change, 100, 263-277.

Gehrels, W. R., A. J. Long, M. H. Saher, and N. Barlow (2012), High-precision reconstructions of relative sea-level changes in the NW Atlantic Ocean during the last 500 years. AGU [abstract]. 2102 Annual Meeting.

González, J. L., and T. E. Törnqvist (2009), A new Late Holocene sea-level record from the Mississippi Delta: Evidence for a climate/sea level connection?, Quat. Sci. Rev., 28, 1737-1749, doi:10.1016/j.quascirev.2009.04.003.

Grinsted, A., J. C. Moore, and S. Jevrejeva (2009), Reconstructing sea level from paleo and projected temperatures 200 to 2100AD, Clim. Dyn., doi:10.1007/s00382-008-0507-2.

Heslop, D., and A. Paul (2011), Can oceanic paleothermometers reconstruct Atlantic Multidecadal Oscillation?, Clim. Past, 7, doi:10.5194/cp-7151-2011.

Hofer, D., C. C. Raible, and T. F. Stocker (2011), Variations of the Atlantic Meridional Overturning Circulation in control and transient simulations of the last millennium, Clim. Past, 7, 133-150, doi:10.5194/cp-7-133-2011.

Hu, A., G. A. Meehl, W. Han, and J. Yin (2009), Transient response of the MOC and climate to potential melting of the Greenland Ice Sheet in the 21st century, Geophys. Res. Lett., 36, L10707, doi:10.1029/2009GL037998.

Jevrejeva, S., J. C. Moore, A. Grinsted, and P. L. Woodworth (2008), Recent global sea level acceleration started over 200 years ago?, Geophys. Res. Lett., 35, L08715, doi:10.1029/2008GL033611.

Jungclaus, J. H., H. Haak, M. Latif, and U. Mikolajewicz (2005), Arctic-North Atlantic interactions and multidecadal variability of the meridional overturning circulation, J. Clim., 18, 4013-4031.

Kearney, M. S., and J. C. Stephenson (1991), Island land loss and marsh vertical accretion rate evidence for historical sea-level changes in Chesapeake Bay, J. Coastal Res., 7, 403-416.

Kemp, A. C., B. P. Horton, J. P. Donnelly, M. E. Mann, M. Vermeer, and S. Rahmstorf (2011), Climate related sea-level variations over the past two millennia, Proc. Natl. Acad. Sci. U. S. A., doi:10.1073/pnas.1015619108.

Kemp, A. C., B. P. Horton, C. H. Vane, C. E. Bernhardt, D. R. Corbett, S. E. Engelhart, S. C. Anisfeld, A. C. Parnell, and N. Cahill (2013), Sea-leve change during the last 2500 years in New Jersey, USA, Quat. Sci. Rev., 81, 90-104, doi:10.1016/j.quascirev.2013.09.024.

Knudsen, M. F., M.-S. Seidenkrantz, B. H. Jacobsen, and A. Kuijpers (2011), Tracking the Atlantic Multidecadal Oscillation through the last 8,000 years, Nat. Commun., 2, 178, doi:10.1038/ncomms1186.

Kopp, R. E. (2013), Does the mid-Atlantic United States sea-level acceleration hot spot reflect ocean dynamic variability?, Geophys. Res. Lett., 40, 3981-3985, doi:10.1002/grl.50781.

Kuhlbrodt, T., A. Griesel, M. Montoya, A. Levermann, M. Hofmann, and S. Rahmstorf (2007), On the driving processes of the Atlantic meridional overturning circulation, Rev. Geophys., 45, RG2001, doi:10.1029/2004RG00166.

Levermann, A., A. Griesel, M. Hofmann, M. Montoya, and S. Rahmstorf (2005), Dynamic sea level changes following changes in the thermohaline circulation, Clim. Dyn., 24, 347-354, doi:10.1007/s00382-004-0505-y.

Liu, Z. (2012), Dynamics of interdecadal climate variability: A historical perspective, J. Clim., 25, 1963-1995, doi:10.1175/2011JCLI3980.1.

Lozier, M. S., V. Roussenov, M. S. C. Reed, and R. G. Williams (2010), Opposing decadal changes for the North Atlantic meridional overturning circulation, Nat. Geosci., 3, 728-734, doi:10.1038/NGEO947.

Lund, D. C., and W. B. Curry (2006), Florida Current surface temperature and salinity variability during the last millennium, Paleoceanography, 21, PA2009, doi:10.1029/2005PA001218.

Lund, D. C., J. Lynch-Stieglitz, and W. B. Curry (2006), Gulf stream density structure and transport during the past millennium, Nature, 444, 601-604, doi:10.1038/nature05277.

Maximenko, N. A., and P. P. Niiler (2005), Hybrid decade-mean global seal level with mesoscale resolution, in Recent Advances in Marine Science and Technology, edited by N. Saxena, pp. 55-59, PACON linternational, Honolulu.

McCarthy, G., E. Frajka-Williams, W. E. Johns, M. O. Baringer, C. S. Meinen, H. L. Bryden, D. Rayner, A. Duchez, C. D. Roberts, and S. A. Cunningham (2012), Observed interannual variability of the Atlantic Meridional Overturning Circulation at $26.5^{\circ} \mathrm{N}$, Geophys. Res. Lett. 39, L19609, doi:10.1029/2012GL052933.

Nicholls, R. J., and A. Cazenave (2010), Sea-level rise and its impact on coastal zones, Science, 328, 1517-1520, doi:10.1126/science.1185782.

Nydick, K., A. Bidwell, E. Thomas, and J. C. Varekamp (1995), A sea-level rise curve from Guilford, CT, Mar. Geol., 124, 137-159.

Rahmstorf, S. (2007), A semi-empirical approach to projecting future sea-level rise, Science, 315, 368-370, doi:10.1126/science.1135456.

Rayner, D., et al. (2011), Monitoring the Atlantic Meridional Overturning Circulation, Deep Sea Res., Part II, 58, 1744-1753, doi:10.1016/j. dsr2.2010.10.056.

Rayner, N. A., D. E. Parker, E. B. Horton, C. K. Folland, L. V. Alexander, and D. P. Rowell (2003), Global analyses of sea surface temperature, sea ice, and night marine air temperature since the late nineteenth century, J. Geophys. Res., 108(D14), 4407, doi:10.1029/2002JD002670.

Reimer, P. J., et al. (2004), INTCAL04 terrestrial radiocarbon age calibration, 0-26 cal kyr BP, Radiocarbon, 46, 1029-1058.

Rossby, T., C. Flagg, and K. Donohue (2010), On the variability of Gulf Stream transport from seasonal to decadal timescales, J. Mar. Res., 68, 503-522.

Sallenger, A. H., Jr., K. S. Doran, and P. A. Howd (2012), Hotspot of accelerated sea-level rise on the Atlantic coast of North America, Nat. Clim. Change, doi:10.1038/nclimate1597.

Schaeffer, M., W. Hare, S. Rahmstorf, and M. Vermeer (2012), Long-term sea-level rise implied by $1.5^{\circ} \mathrm{C}$ and $2^{\circ} \mathrm{C}$ warming levels, Nat. Clim. Change, doi:10.1038/NCLIMATE1584.

Schlesinger, M. E., and N. Ramankutty (1994), An oscillation in the global climate system of period $65 \pm 70$ years, Nature, 367, 723-726. 
Scholl, D. W., F. C. Craighead, and M. Stuiver (1969), Florida submergence curve revised: Its relation to coastal sedimentation rates, Science, $163,562-564$

Srokosz, M., M. Baringer, H. Bryden, S. Cunningham, T. Delworth, S. Lozier, J. Marotzke, and R. Sutton (2012), Past, present, and future changes in the Atlantic Meridional Overturning Circulation, Bull. Am. Meteorol. Soc., 93, 1663-1676.

Stuiver, et al. (2012), CALIB radiocarbon calibration version 6.0. [Available at http://calib.qub.ac.uk/calib/.]

te Raa, L. A., and H. Dijkstra (2002), Instability of the thermohaline ocean circulation on interdecadal timescales, J. Phys. Oceanog., 32, 138-160.

Thomas, E., and J. C. Varekamp (1991), Paleo-environmental analyses of marsh sequences (Clinton, CT): Evidence for punctuated rise in relative sea-level during the latest Holocene, J. Coastal Res., Special Issue, 11, 125-158.

Thompson, W. G., E. Thomas, and J. C. Varekamp (2000), 1500 years of sea level rise in long island sound, in Proceedings of the Fourth Biennial Long Island Sound Research Conference, edited by R. B. Whitlatch and J. R. Wood-Martin, pp. 139-148, Connecticut Sea Grant Program, Groton, Conn.

Trouet, V., J. Esper, N. E. Graham, A. Baker, J. D. Scourse, and D. C. Frank (2009), Persistent positive North Atlantic Oscillation mode dominated the Medieval Climate Anomaly, Science, 324, 78-80.

van de Plassche, O., K. van der Borg, and A. F. M. de Jong (1998), Sea level-climate correlation during the past 1400 yr, Geology, 26, 319-322.

van de Plassche, O., G. Erkens, F. van Vliet, J. Brandsma, K. van der Borg, and A. F. M. de Jong (2006), Salt-marsh erosion associated with hurricane landfall in southern New England in the fifteenth and seventeenth centuries, Geology, 34, 829-832.

Vann, C. D., T. M. Cronin, and G. S. Dwyer (2004), Population ecology and shell chemistry of a phytal ostracode species (Loxoconcha matagordensis) in the Chesapeake Bay watershed, Mar. Micropaleont., 53, 261-277.

Varekamp, J. C., and E. Thomas (1998), Climate change and the rise and fall of sea level over the millennium, Eos Trans. AGU, 79(6), 69, doi:10.1029/98EO00046.

Varekamp, J. C., E. Thomas, and O. van de Plassche (1992), Relative sea-level rise and climate change over the last 1500 years, Terra Nova, 4 , 293-304.

Vellinga, M., and P. Wu (2004), Low-latitude freshwater influence on centennial variability of the Atlantic thermohaline circulation, J. Clim., 17 , 4498-4511.

Vermeer, M., and S. Rahmstorf (2009), Global sea level linked to global temperature, Proc. Natl. Acad. Sci. U. S. A., doi:10.1073/ pnas.0907765106.

Willard, D. A., C. E. Bernhardt, D. A. Korejwo, and S. R. Meyers (2005), Impact of millennial-scale Holocene climate variability on eastern North American terrestrial ecosystems: Pollen-based climatic reconstruction, Global Planet. Change, 47, 17-35.

Wyatt, M. G., S. Kravtsov, and A. A. Tsonis (2011), Atlantic Multidecadal Oscillation and Northern Hemisphere's climate variability, Clim. Dyn., 38, 929-949, doi:10.1007/s00382-011-1071-8.

Yin, J., M. E. Schlesinger, and R. J. Stouffer (2009), Model projections of rapid sea-level rise on the northeast coast of the United States, Nat. Geosci., 2, 262-266, doi:10.1038/NGEO462. 